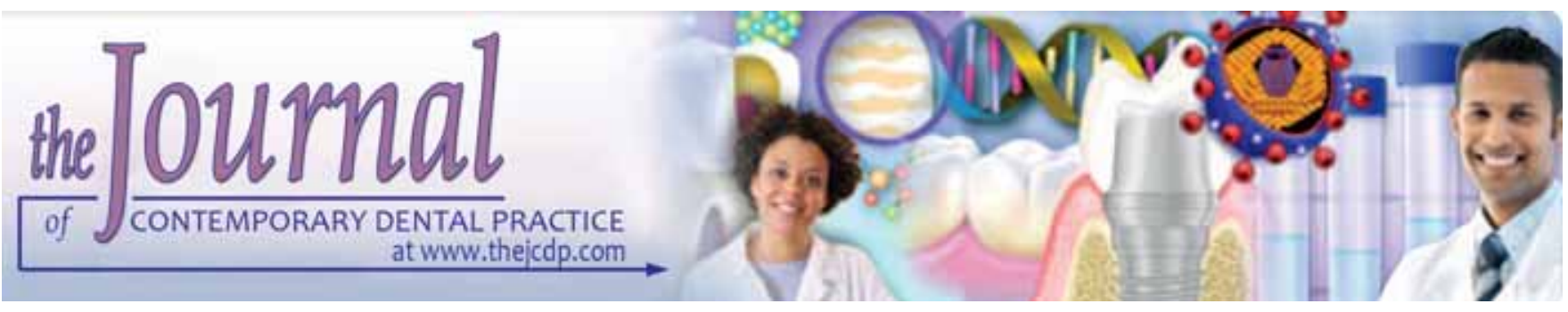

\title{
Effects of lodine in Microbial Control of Dental Treatment Water
}

\author{
Raghunath Puttaiah, Jeff Seibert, Robert Spears
}

\begin{abstract}
Objective: To determine the effects of low levels of iodine constantly present in the dental unit water system on microbial control of dental treatment water and biofilm control.
\end{abstract}

Materials and methods: This study used a dental unit water system simulator with eight dental unit waterline systems built to scale and function, each controlled via computer. Each of the eight units was operated independently, four units supplied with self-contained water reservoirs and four units supplied with municipal water. Four units were precleaned to remove biofilm buildup. The study had a well-balanced design with equal representation (variables) of presence/absence of biofilms, selfcontained reservoirs for introduction of treatment water, source water directly connected to municipal water source and iodinated cartridges within the self-contained reservoirs and between municipal water and dental unit. Point-of-use iodinated resin cartridges (IRC) were retrofitted proximal to handpiece and air/ water syringe tip lines in four units, and iodinated resin water cartridges (IRSWC) were fitted to the other four units at the source water output. Heterotrophic plate counts were performed at baseline and twice weekly for a period of 6 weeks. One representative waterline sample was taken from each group at baseline and end-of-study to analyze changes in biofilm status using scanning electron microscopy.

Results: Waterlines not previously contaminated with biofilms did not show organization of biofilm matrix in units equipped with IRSWC. Constantly present low levels of iodine, demonstrated some disruption of biofilms in waterlines already contaminated with mature biofilms. All groups showed contamination levels $<500 \mathrm{cfu} / \mathrm{ml}$ (colony forming units per milliliter) consistent with the CDC and ADA guidelines.

Conclusion: In this 6 weeks study, IRSWC equipped waterlines showed disruption of established biofilms, controlled formation of new biofilms in clean lines and rendered the dental treatment water $<500 \mathrm{cfu} / \mathrm{ml}$. Point-of-use iodinated resin cartridges were also effective in controlling contamination in the dental treatment water.

Clinical significance: Dental unit water systems that are in use get contaminated with microbes and biofilms in weeks of being put into use. These biofilms contaminate the treatment water thereby putting patients and staff at risk of infection by predominantly gram-negative microbes. Biofilms in the water systems must be cleaned periodically with a strong decontaminant and the dental treatment source water needs to be modified with a low-grade antimicrobial that can preserve the water quality yet safe to humans. In this translational research study, we evaluate the effects of elemental iodine dissolved in water flowing through an iodine containing cartridge in controlling biofilm and dental treatment water contamination using a dental unit water system simulator, prior to clinical utilization.

Keywords: Waterline biofilms, Dental treatment water, Heterotrophic counts, Scanning electron microscopy, lodine.

How to cite this article: Puttaiah R, Seibert J, Spears R. Effects of Iodine in Microbial Control of Dental Treatment Water. J Contemp Dent Pract 2011;12(3):143-151.

Source of support: Nil

Conflict of interest: None declared

\section{BACKGROUND}

The formation of dental waterline biofilms has been well documented..$^{1-4}$ Biofilm contamination is a dynamic process facilitated by several factors. Some of the reasons biofilms form in the lumens of dental unit waterlines (DUWLs) include but not limited to are: Extended periods of water stagnation, fluid mechanics of maximum flow-rate in the center of line and very low movement along the periphery of the lumen (laminar flow), high surface area-to-volume ratio of waterline tubing given flow-rate, nutrient content (mineral and inorganic) of water, coating of lines with inorganic salts, type of waterline material and the microbial quality of water entering the dental unit. Microbial content of dental unit water (DUW) has been extensively studied and settling and amplification of microorganisms in DUWLs has been previously demonstrated. ${ }^{5-12}$ Biofilms are composed of various species of microorganisms with some being potentially pathogenic. It is important to implement effective means of controlling formation of biofilms so that the CDC and ADA guidelines of $<500 \mathrm{CFU} / \mathrm{ml}$ heterotrophic mesophilic microorganisms for dental treatment water can be achieved. ${ }^{13}$ 
Several methods have been suggested by which the contamination of DUWLs might be minimized or avoided. Many dental units today are equipped with antiretraction valves to prevent suck-back or are designed to give a short terminal flush of water through handpieces after operation. ${ }^{14}$ Flushing of DUWLs at the beginning and at the end of patient treatment has been previously advocated. ${ }^{15,16}$ Although the suggested flushing protocol recommended by the US Department of Health and Human Services ${ }^{17}$ may diminish planktonic (free-floating) organisms momentarily, it does not eliminate or control biofilm. One study concluded that a two-minute flush reduced the counts of planktonic organisms, on average, by one-third but did not reduce counts to zero. ${ }^{18}$

Tap water can be treated in a variety of ways to provide treatment water that will meet the ADA goal. Boiling, pasteurization, filtration, distillation, sterilization and utilization of chemical additives are some of the methods that may be efficacious in controlling the level of contamination in source water. Many authors have suggested flushing waterlines with various disinfectant solutions, such as hydrogen peroxide, ${ }^{19}$ chlorhexidine gluconate, ${ }^{20}$ sodium hypochlorite, ${ }^{21}$ povidone-iodine ${ }^{22}$ and mouthwash. ${ }^{23}$ Each of these methods, though effective at temporarily controlling biofilms, does not eliminate biofilm formation due to the inherent contamination of source or city water supplies. Use of sodium hypochlorite is effective in controlling biofilms and improving dental treatment water quality, but there are drawbacks. Sodium hypochlorite is very corrosive and can be damaging to the DUW system. In addition, high amounts of trihalomethanes are produced when in contact with organic matter, including biofilms. ${ }^{24}$

The microbial quality and mineral content of tap water vary depending upon processing, distance from the processing plant, inherent mineral content, as well as seasonal variations. Simply cleaning/disinfecting DUWLs periodically does not ensure that DUW can meet the ADA's goal. In order to control contamination from source water, dental units are now being retrofitted with self-contained water reservoirs. The retrofit of these units along with the use of distilled water does not however address the concern of the biofilms already present within the DUWLs. Periodic or continuous-release chemical treatment to control microbes and biofilm in DUWLs have been suggested, such as citric acid, ${ }^{25}$ chlorhexidine ${ }^{26}$ and iodine. When selecting a chemical treatment, it is necessary to use chemicals and methods that are known to be safe for DUWLs. The agent(s) must be approved by the appropriate governmental agencies (FDA and EPA) for use in the US, safe for patients, noncorrosive to DUWL components and compatible with other materials used in the patient's mouth.
Iodine is an effective antimicrobial agent and has been used in dentistry as a presurgical paint to reduce intraoral microorganisms. Levels of iodine up to $1,000 \mathrm{mg} /$ day for children and 2,000 mg/day for adults have shown no adverse health effects. ${ }^{27}$ The recommended dietary allowance (RDA) is 150 micrograms of iodine per day. ${ }^{28}$ The DentaPure cartridge filters (MRLB International, River Falls, WI) elute 2 to 6 parts per million (ppm) of iodine as water is passed through the iodinated resin bed of the filter. A typical dental treatment session uses less than $100 \mathrm{ml}$ of water and saliva ejectors aspirate most of this treated water. During dental treatment, the oral cavity is only wetted by water and a minimal may be ingested or absorbed by the body, leaving the patient with an iodine dosage lesser than the US RDA.

Postsurgical dental care commonly prescribes rinsing four to five times daily with warm salt water as an aid to the healing process. A $100 \mathrm{ml}$ volume of water containing a teaspoon of iodized salt contains 240 micrograms of iodine. It is then reasonable to surmise that constantly present low levels of iodine in dental treatment water may be as safe as warm salt water rinses which have long been a staple of postsurgical recommendations. If this constantly present, iodine could control biofilm formation in DUWLs, then a method for its use to control biofilm formation in dentistry may be proved to be effective and safe. Therefore, this study was designed to test this hypothesis.

\section{MATERIALS AND METHODS}

A dental unit waterline simulation system was designed and developed by Drs R Puttaiah, J Siebert (Baylor College of Dentistry) and J Zawada (A-dec Corp, Newberg, OR) for use in this study. A schematic of this system is shown in Figure 1. This device simulated eight dental unit waterline systems to scale and operation of the system was computer controlled. Each of the eight units operated independently via a logic control device that was automated to simulate a standardized flow of water. Iodinated resin cartridges (IRC) or point-of-use filters (Fig. 1) were retrofitted to the system proximal to the handpiece and air/water syringe tips in a balanced design. Iodinated resin supply water cartridges (IRSWC) or base filters (Fig. 1) were connected to half of the units at the source water connection. Water to four of the units was supplied from self-contained reservoirs and the other four were connected directly to the municipal water supply.

Eight control-block manifold units each with four handpiece and one air/water syringe lines were tested. Effects of cartridge placement proximal versus distal to the effluent water source were studied. In addition, the effects of self-contained water reservoirs versus direct rigging to the municipal water supply were evaluated. Group 1 
comprised of dental units 1 through 4 (C1 - C4 as seen in Fig. 1). The layout for the IRC, IRSWC and water source connection can be seen in the schematic (Fig. 1). The waterlines for this group were free from biofilm contamination at the beginning of the study. Group 2 comprised of dental units 5 through 8 (C5 - C8 as seen in Fig. 1). The layout for the IRC, IRSWC and water source connection can be seen in the schematic (Fig. 1). The waterlines for this group had mature biofilms at the beginning of the study.

Heterotrophic plate counts (HPC) were performed at baseline and twice weekly for a period of 6 weeks. Counts also were taken from the source water (self-contained reservoirs and municipal water). Pre-IRC water samples were taken in all the combination treatment groups. Pooled effluent water from four handpiece and one air/water syringe lines was tested. Samples were taken following the overnight stagnation period at midweek and at the end of the week. These samples were collected for each unit C1-C8 and the total group volume did not exceed $20 \mathrm{ml}$. Samples were vortexed, plated on R2A agar (Remel, Lenexa, KS) with phosphate buffer in the media and readouts recorded in colonyforming units per milliliter (CFU/ml) after being incubated for 7 days at 22 to $24^{\circ} \mathrm{C}$.

Scanning electron microscopy on representative lines per group at baseline and end-of-study. Samples were collected in 3\% glutaraldehyde (fixed for one and half hours), dehydrated with alcohol, mounted to disks, coated with gold palladium and scanned at $1500 \times$ under a scanning electron microscope (JEOL JSM 6300) to determine the presence or absence of biofilm.

Iodine levels in the water samples were collected from municipal water, post-IRSWC cartridge, pre-IRC and postIRC at the end of weeks 2 and 4 in order to evaluate the levels of iodine at different areas of the system. Water was collected in prescribed containers, which were free of trace elements and samples were shipped overnight on ice to a testing laboratory. Free iodine and iodide levels were calculated using standard methods. ${ }^{29}$ THMs and disinfection-by-product contamination were tested using a one-time water sampling during week 4. Samples were shipped on ice to the testing laboratory using prescribed EPA methods. ${ }^{30}$

Statistical analysis of heterotrophic plate counts was conducted after the absolute values of heterotrophic plate counts were converted to $\log _{10}$. The hypothesis was that there were no differences between the effects within and between the groups. The heterotrophic plate counts of source water, prepoint-of-use cartridge and effluent water samples for each group were analyzed using one-way analysis of variance (ANOVA) with applicable posthoc tests (Scheffe's test). All analyses were conducted at an alpha of 0.05 .

While handling the water, waterline specimens, chemicals and sterile items, personal protective equipment and barriers were used as per institutional protocols. All samples were analyzed according to standard microbiological requirements. Waste handling was carried out using routine institutional guidelines.

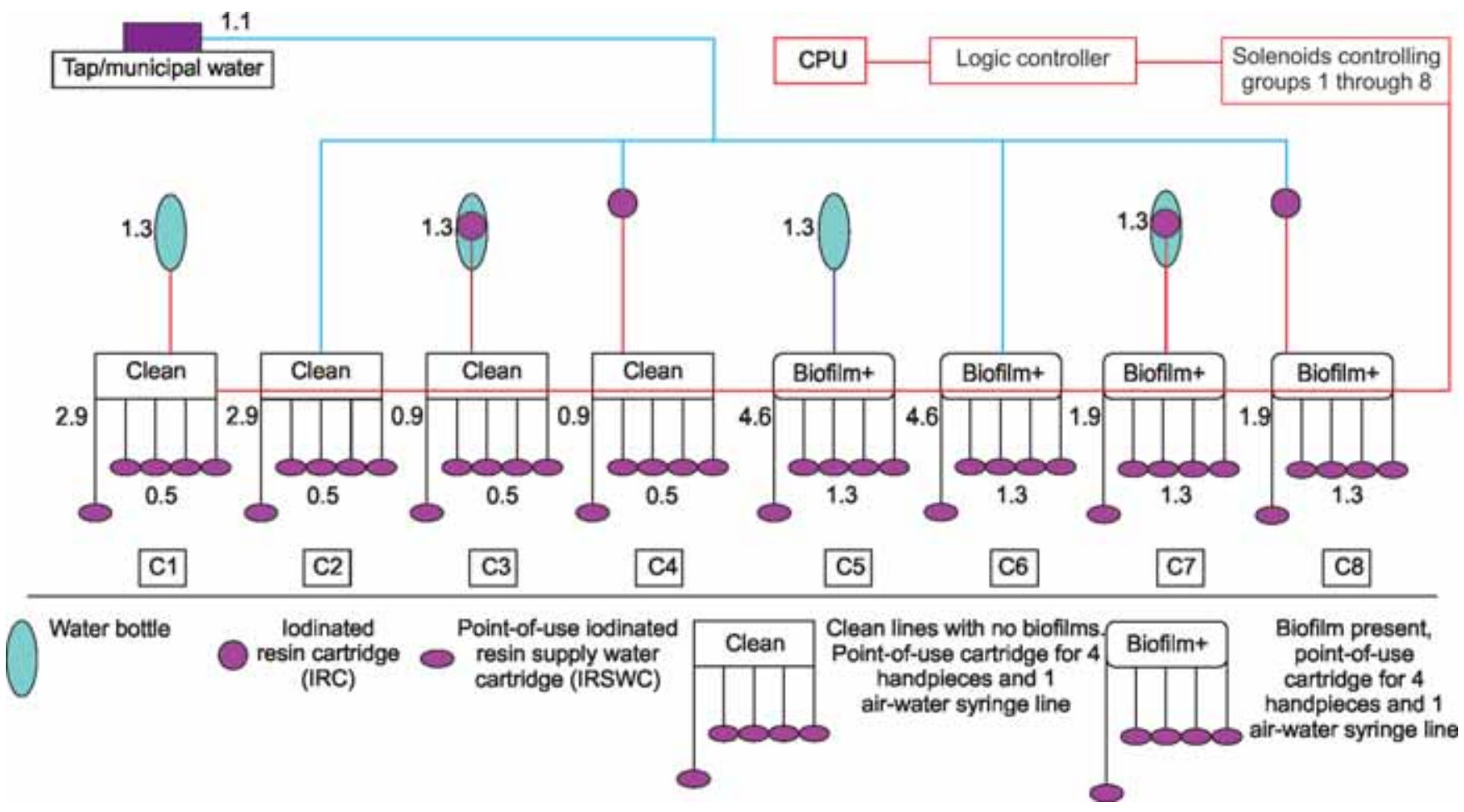

Fig. 1: $\log _{10}$ values of mean heterotrophic plate counts [(1.1) Municipal water, (1.3) Source Water, (2.9) prepoint-of-use, (1.5) postpoint-of-use] in simulated dental unit water system with iodine cartridges 


\section{RESULTS}

Absolute $\log _{10}$ values are shown for source water from the municipal water, self-contained water system/bottle, prebase cartridge, prepoint-of-use cartridge and postpoint-of-use cartridge are shown in Figure 1, Tables 1A to 1D. The mean contamination of municipal water and water reservoir samples was approximately $1.1 \log _{10} \mathrm{CFU} / \mathrm{ml}$. The mean contamination prior to the control blocks in units rigged to municipal water was $4.6 \log _{10} \mathrm{CFU} / \mathrm{ml}$ and the mean for self-contained reservoirs ranged from 0.7 to $1.8 \log _{10} \mathrm{CFU} /$ $\mathrm{ml}$. The pre-IRC contamination levels for $\mathrm{C} 1$ and $\mathrm{C} 2$ which did not have base cartridges and began the study with biofilm free waterlines showed a mean contamination ranging from 2.5 to $3.2 \log _{10} \mathrm{CFU} / \mathrm{ml}$ which can be contrasted with C5 and C6 which did not have base cartridges, but started the study with biofilm contamination had a mean contamination of $4.6 \log _{10}$ CFU/ml (Fig. 1). C3 and C4 which had base cartridges and were biofilm free showed a mean contamination from 0.8 to $1.0 \log _{10} \mathrm{CFU} / \mathrm{ml}$ contrasted with C7 and C8 which had biofilms and demonstrated a mean contamination of $1.9 \log _{10} \mathrm{CFU} / \mathrm{ml}$. Prepoint-of-use cartridge water in groups C5 and C6 had the highest levels of contamination $4.6 \log _{10} \mathrm{CFU} / \mathrm{ml}$ and $1.9 \log _{10} \mathrm{CFU} / \mathrm{ml}$ respectively. $\mathrm{C} 1$ and $\mathrm{C} 2$, which were clean at the beginning of the study, became significantly more contaminated than C3 and C4 (2.5 and $3.2 \log _{10} \mathrm{CFU} / \mathrm{ml}$ versus 1.0 and 0.8 $\left.\log _{10} \mathrm{CFU} / \mathrm{ml}\right)$. Post-IRC of effluent water contamination over the 6-week period ranged from 0.4 to $1.8 \log _{10} \mathrm{CFU} / \mathrm{ml}$. $\mathrm{C} 1$ and $\mathrm{C} 2\left(0.4 \log _{10} \mathrm{CFU} / \mathrm{ml}\right)$ showed the least amount of contamination and C5 (1.8 $\left.\log _{10} \mathrm{CFU} / \mathrm{ml}\right)$ showed the greatest. All groups demonstrated mean contamination level less than $200 \mathrm{CFU} / \mathrm{ml}$, which is consistent with the ADA goal for the year 2000. One-way ANOVA comparison of heterotrophic plate counts of source waters, prepoint-ofuse samples and effluent samples are shown in Table 2 . Presence of iodine in the lines showed lower microbial counts in comparative units $(\mathrm{p}<0.05)$.

Based on the outcomes of statistical evaluation, water collected from the tap was not significantly more contaminated than the effluent from all groups ( $p>0.05)$. Water collected just before the control block in groups connected to the municipal water was significantly more contaminated than the effluent water from all groups and source water in the groups with self-contained water systems $(\mathrm{p}<0.05)$. Water collected post-IRSWC and pre-IRC was less contaminated than those not supplied by the IRSWC ( $<0.05)$. Iodine and iodide levels of water from different locations in the system ranged from 0.1 to $6.7 \mathrm{ppm}$.

\begin{tabular}{|c|c|c|c|c|c|c|c|}
\hline \multicolumn{2}{|l|}{ Sample } & \multirow{2}{*}{$\begin{array}{c}\text { Tap } \\
43\end{array}$} & \multirow{2}{*}{$\begin{array}{c}\text { Prebase } \\
40000\end{array}$} & \multirow{2}{*}{$\begin{array}{c}\text { C1 source } \\
00\end{array}$} & \multirow{2}{*}{$\begin{array}{c}\text { C3 source } \\
00\end{array}$} & \multirow{2}{*}{$\begin{array}{c}\text { C5 source } \\
00\end{array}$} & \multirow{2}{*}{$\begin{array}{c}\text { C7 source } \\
00\end{array}$} \\
\hline Baseline & (abs) & & & & & & \\
\hline & $\left(\log _{10}\right)$ & 1.63 & 4.6 & 0.0 & 0.0 & 0.0 & 0.0 \\
\hline \multirow{2}{*}{ Week $1 \mathrm{~A}$} & (abs) & 00 & 40000 & 00 & 10 & 20 & 10 \\
\hline & $\left(\log _{10}\right)$ & 0.0 & 4.6 & 0.0 & 1.0 & 1.3 & 1.0 \\
\hline \multirow[t]{2}{*}{ Week 1B } & (abs) & 02 & 31900 & 10 & 30 & 00 & 40 \\
\hline & $\left(\log _{10}\right)$ & 0.0 & 4.5 & 1.0 & 1.48 & 0.0 & 1.6 \\
\hline \multirow[t]{2}{*}{ Week 2A } & (abs) & 05 & 40000 & 30 & 00 & 20 & 10 \\
\hline & $\left(\log _{10}\right)$ & 0.7 & 4.6 & 1.48 & 0.0 & 1.3 & 1.0 \\
\hline \multirow[t]{2}{*}{ Week 2B } & (abs) & 14 & 40000 & 40 & 00 & 60 & 00 \\
\hline & $\left(\log _{10}\right)$ & 1.15 & 4.6 & 1.6 & 0.0 & 1.78 & 0.0 \\
\hline \multirow[t]{2}{*}{ Week $3 \mathrm{~A}$} & (abs) & 6 & 40000 & 70 & 00 & 00 & 50 \\
\hline & $\left(\log _{10}\right)$ & 0.78 & 4.6 & 1.85 & 0.0 & 0.0 & 1.7 \\
\hline \multirow[t]{2}{*}{ Week 3B } & (abs) & 3 & 40000 & 30 & 00 & 300 & 00 \\
\hline & $\left(\log _{10}\right)$ & 0.48 & 4.6 & 1.48 & 0.0 & 2.48 & 0.0 \\
\hline \multirow[t]{2}{*}{ Week 4A } & (abs) & 16 & 40000 & 40 & 00 & 00 & 00 \\
\hline & $\left(\log _{10}\right)$ & 1.2 & 4.6 & 1.60 & 0.0 & 0.0 & 0.0 \\
\hline \multirow[t]{2}{*}{ Week 4B } & (abs) & 21 & 40000 & 10 & 10 & 00 & 30 \\
\hline & $\left(\log _{10}\right)$ & 1.32 & 4.6 & 1.0 & 1.0 & 0.0 & 1.48 \\
\hline \multirow[t]{2}{*}{ Week $5 \mathrm{~A}$} & (abs) & 00 & 40000 & 980 & 60 & 160 & 30 \\
\hline & $\left(\log _{10}\right)$ & 0.0 & 4.6 & 2.99 & 1.78 & 2.2 & 1.48 \\
\hline \multirow[t]{2}{*}{ Week 5B } & (abs) & 49 & 40000 & 400 & 10 & 4000 & 570 \\
\hline & $\left(\log _{10}\right)$ & 1.69 & 4.6 & 2.6 & 1.0 & 3.6 & 2.76 \\
\hline \multirow[t]{2}{*}{ Week $6 \mathrm{~A}$} & (abs) & 83 & 40000 & 4000 & 10 & 4000 & 40 \\
\hline & $\left(\log _{10}\right)$ & 1.92 & 4.6 & 3.6 & 1.0 & 3.6 & 1.6 \\
\hline \multirow[t]{2}{*}{ Week 6B } & (abs) & 230 & 40000 & 4000 & 20 & 4000 & 40 \\
\hline & $\left(\log _{10}\right)$ & 2.36 & 4.6 & 3.6 & 1.3 & 3.6 & 1.6 \\
\hline
\end{tabular}

- $\quad$ C1, C3, C5, C7 had self-contained reservoirs (bottle systems), all bottles were filled with water directly from the tap (municipal water)

- A lead line from the tap (6 feet long) provided additional source of contamination $>40000 \mathrm{CFU} / \mathrm{ml}$ and samples collected postlead line and before control block was prebase, and provided water to C2, C4, C6 and C8. Groups C3, C4, C7 and C8 had base cartridges 


\begin{tabular}{|c|c|c|c|c|c|c|c|c|c|}
\hline Sample & & C1 pre & C2 pre & C3 pre & C4 pre & C5 pre & C6 pre & C7 pre & C8 pre \\
\hline \multirow[t]{2}{*}{ Baseline } & (abs) & 00 & 00 & 00 & 00 & 40000 & 40000 & 31500 & 14500 \\
\hline & $\left(\log _{10}\right)$ & 0.0 & 0.0 & 0.0 & 0.0 & 4.6 & 4.6 & 4.5 & 4.16 \\
\hline \multirow[t]{2}{*}{ Week $1 \mathrm{~A}$} & (abs) & 30 & 50 & 00 & 00 & 40000 & 40000 & 8600 & 3100 \\
\hline & $\left(\log _{10}\right)$ & 1.48 & 1.7 & 0.0 & 0.0 & 4.6 & 4.6 & 3.93 & 3.49 \\
\hline \multirow[t]{2}{*}{ Week 1B } & (abs) & 20 & 4000 & 00 & 40 & 26400 & 27300 & 2500 & 300 \\
\hline & $\left(\log _{10}\right)$ & 1.3 & 3.6 & 0.0 & 1.6 & 4.42 & 4.44 & 3.4 & 2.48 \\
\hline \multirow[t]{2}{*}{ Week $2 \mathrm{~A}$} & (abs) & 410 & 3210 & 00 & 00 & 23900 & 27600 & 80 & 680 \\
\hline & $\left(\log _{10}\right)$ & 2.61 & 3.5 & 0.0 & 0.0 & 4.38 & 4.44 & 1.9 & 2.83 \\
\hline \multirow[t]{2}{*}{ Week 2B } & (abs) & 70 & 4000 & 00 & 20 & 40000 & 40000 & 10 & 20 \\
\hline & $\left(\log _{10}\right)$ & 1.85 & 3.6 & 0.0 & 1.3 & 4.6 & 4.6 & 1.0 & 1.3 \\
\hline \multirow[t]{2}{*}{ Week 3A } & (abs) & 2610 & 4000 & 10 & 30 & 40000 & 40000 & 20 & 40 \\
\hline & $\left(\log _{10}\right)$ & 3.42 & 3.6 & 1.0 & 1.48 & 4.6 & 4.6 & 1.3 & 1.6 \\
\hline \multirow[t]{2}{*}{ Week 3B } & (abs) & 130 & 4000 & 00 & 00 & 40000 & 40000 & 30 & 10 \\
\hline & $\left(\log _{10}\right)$ & 2.11 & 3.6 & 0.0 & 0.0 & 4.6 & 4.6 & 1.48 & 1.0 \\
\hline \multirow[t]{2}{*}{ Week 4A } & (abs) & 380 & 4000 & 110 & 00 & 40000 & 40000 & 10 & 10 \\
\hline & $\left(\log _{10}\right)$ & 2.58 & 3.6 & 2.04 & 0.0 & 4.6 & 4.6 & 1.0 & 1.0 \\
\hline \multirow[t]{2}{*}{ Week 4B } & (abs) & 790 & 4000 & 120 & 00 & 40000 & 40000 & 10 & 10 \\
\hline & $\left(\log _{10}\right)$ & 2.9 & 3.6 & 2.08 & 0.0 & 4.6 & 4.6 & 1.0 & 1.0 \\
\hline \multirow[t]{2}{*}{ Week 5A } & (abs) & 4000 & 4000 & 10 & 10 & 40000 & 40000 & 00 & 10 \\
\hline & $\left(\log _{10}\right)$ & 3.6 & 3.6 & 1.0 & 1.0 & 4.6 & 4.6 & 0.0 & 1.0 \\
\hline \multirow[t]{2}{*}{ Week 5B } & (abs) & 4000 & 4000 & 270 & 10 & 40000 & 40000 & 00 & 10 \\
\hline & $\left(\log _{10}\right)$ & 3.6 & 3.6 & 2.43 & 0.0 & 4.6 & 4.6 & 0.0 & 1.0 \\
\hline \multirow[t]{2}{*}{ Week 6A } & (abs) & 4000 & 4000 & 80 & 30 & 40000 & 40000 & 150 & 30 \\
\hline & $\left(\log _{10}\right)$ & 3.6 & 3.6 & 1.9 & 1.48 & 4.6 & 4.6 & 2.18 & 1.48 \\
\hline \multirow[t]{2}{*}{ Week 6B } & (abs) & 4000 & 4000 & 340 & 310 & 40000 & 40000 & 220 & 80 \\
\hline & $\left(\log _{10}\right)$ & 3.6 & 3.6 & 2.53 & 2.49 & 4.6 & 4.6 & 2.34 & 1.9 \\
\hline
\end{tabular}

C3, C4, C7 and C8 have base cartridges and showed contamination levels that were below $500 \mathrm{CFU} / \mathrm{ml}$ after the first part of week 2. C5 and $\mathrm{C} 6$ had no exposure to iodine and consistently showed $>40,000 \mathrm{CFU} / \mathrm{ml}$. C1 and C2 showed unacceptable contamination levels by the end of the 1st week of the study

Table 1C: Heterotrophic plate counts of effluent water collected after (post) point-of-use cartridges (absolute and $\log _{10}$ counts)

\begin{tabular}{|c|c|c|c|c|c|c|c|c|c|}
\hline \multicolumn{2}{|l|}{ Sample } & C1E & $C 2 E$ & C3E & C4E & C5E & C6E & C7E & C8E \\
\hline \multirow{2}{*}{$\begin{array}{l}\text { Sample } \\
\text { Baseline }\end{array}$} & (abs) & 00 & 00 & 30 & 50 & 2180 & 4000 & 400 & 400 \\
\hline & $\left(\log _{10}\right)$ & 0.0 & 0.0 & 1.48 & 1.7 & 3.34 & 3.6 & 2.6 & 2.6 \\
\hline \multirow[t]{2}{*}{ Week $1 \mathrm{~A}$} & (abs) & 00 & 00 & 40 & 01 & 870 & 120 & 770 & 90 \\
\hline & $\left(\log _{10}\right)$ & 0.0 & 0.0 & 1.6 & 0.0 & 2.94 & 2.08 & 2.89 & 1.95 \\
\hline \multirow[t]{2}{*}{ Week 1B } & (abs) & 00 & 00 & 00 & 16 & 480 & 20 & 90 & 30 \\
\hline & $\left(\log _{10}\right)$ & 0.0 & 0.0 & 0.0 & 1.2 & 2.68 & 1.3 & 1.95 & 1.48 \\
\hline \multirow[t]{2}{*}{ Week 2A } & (abs) & 10 & 10 & 10 & 00 & 80 & 60 & 180 & 110 \\
\hline & $\left(\log _{10}\right)$ & 1.0 & 1.0 & 1.0 & 0.0 & 1.9 & 1.78 & 2.26 & 2.04 \\
\hline \multirow[t]{2}{*}{ Week 2B } & (abs) & 00 & 00 & 00 & 00 & 30 & 10 & 00 & 70 \\
\hline & $\left(\log _{10}\right)$ & 0.0 & 0.0 & 0.0 & 0.0 & 1.48 & 1.0 & 0.0 & 1.85 \\
\hline \multirow[t]{2}{*}{ Week 3A } & (abs) & 10 & 00 & 30 & 00 & 430 & 20 & 00 & 00 \\
\hline & $\left(\log _{10}\right)$ & 1.0 & 0.0 & 1.48 & 0.0 & 2.63 & 1.3 & 0.0 & 0.0 \\
\hline \multirow[t]{2}{*}{ Week 3B } & (abs) & 00 & 20 & 10 & 10 & 80 & 10 & 00 & 00 \\
\hline & $\left(\log _{10}\right)$ & 0.0 & 1.3 & 1.0 & 1.0 & 1.9 & 1.0 & 0.0 & 0.0 \\
\hline \multirow[t]{2}{*}{ Week 4A } & (abs) & 00 & 10 & 00 & 30 & 00 & 10 & 00 & 00 \\
\hline & $\left(\log _{10}\right)$ & 0.0 & 1.0 & 0.0 & 1.48 & 0.0 & 1.0 & 0.0 & 0.0 \\
\hline \multirow[t]{2}{*}{ Week 4B } & (abs) & 00 & 00 & 00 & 30 & 40 & 10 & 00 & 00 \\
\hline & $\left(\log _{10}\right)$ & 0.0 & 0.0 & 0.0 & 1.48 & 1.6 & 1.0 & 0.0 & 0.0 \\
\hline \multirow[t]{2}{*}{ Week 5A } & (abs) & 10 & 00 & 00 & 10 & 120 & 10 & 40 & 00 \\
\hline & $\left(\log _{10}\right)$ & 1.0 & 0.0 & 0.0 & 1.0 & 2.08 & 1.0 & 1.6 & 0.0 \\
\hline \multirow[t]{2}{*}{ Week 5B } & (abs) & 10 & 10 & 00 & 00 & 10 & 10 & 30 & 40 \\
\hline & $\left(\log _{10}\right)$ & 1.0 & 1.0 & 0.0 & 0.0 & 1.0 & 1.0 & 1.48 & 1.6 \\
\hline \multirow[t]{2}{*}{ Week 6A } & (abs) & 00 & 00 & 10 & 10 & 00 & 00 & 00 & 00 \\
\hline & $\left(\log _{10}\right)$ & 0.0 & 0.0 & 1.0 & 1.0 & 0.0 & 0.0 & 0.0 & 0.0 \\
\hline \multirow[t]{2}{*}{ Week 6B } & (abs) & 10 & 20 & 00 & 00 & 100 & 50 & 40 & 00 \\
\hline & $\left(\log _{10}\right)$ & 1.0 & 1.3 & 0.0 & 0.0 & 2.0 & 1.7 & 1.6 & 0.0 \\
\hline
\end{tabular}

All groups had point-of-use cartridges while $\mathrm{C} 3, \mathrm{C} 4, \mathrm{C} 7$ and $\mathrm{C} 8$ had base cartridges. Irrespective of the presence or absence of base cartridges, the water output through the postpoint-of-use cartridges showed decrease in the number of microbes to acceptable levels (<500 CFU/ml) 


\begin{tabular}{lccccc}
\multicolumn{7}{c}{ Table 1D: Descriptive statistics of heterotrophic plate counts in $\log _{10}$ values } \\
\hline & $N$ & Minimum & Maximum & Mean & SD \\
\hline Tap & 13 & 0.00 & 2.36 & 1.0409 & 0.7429 \\
Prebase & 13 & 4.50 & 4.60 & 4.5500 & 0.3799 \\
C1 source & 13 & 0.00 & 3.60 & 1.7539 & 1.1754 \\
C3 source & 13 & 0.00 & 1.78 & 0.6582 & 0.6711 \\
C5 source & 13 & 0.00 & 3.60 & 1.5283 & 1.4749 \\
C7 source & 13 & 0.00 & 2.76 & 1.0935 & 0.8661 \\
C1 pre & 13 & 0.00 & 3.60 & 1.1249 \\
C2 pre & 13 & 0.00 & 3.60 & 3.1668 & 1.0857 \\
C3 pre & 13 & 0.00 & 2.53 & 0.9990 & 1.0590 \\
C4 pre & 13 & 0.00 & 4.49 & 0.7961 & 0.8462 \\
C5 pre & 13 & 4.38 & 4.60 & 4.5710 & $7.639 \mathrm{E}-02$ \\
C6 pre & 13 & 4.44 & 4.50 & 1.8769 & $6.142 \mathrm{E}-02$ \\
C7 pre & 13 & 0.00 & 4.16 & 1.8651 & 1.4012 \\
C8 pre & 13 & 1.00 & 1.00 & 0.3846 & 1.0610 \\
C1E & 13 & 0.00 & 1.30 & 0.4309 & 0.5064 \\
C2E & 13 & 0.00 & 1.60 & 0.5813 & 0.5753 \\
C3E & 13 & 0.00 & 1.70 & 0.6813 & 0.6794 \\
C4E & 13 & 0.00 & 3.34 & 1.8121 & 0.6871 \\
C5E & 13 & 0.00 & 3.60 & 1.3662 & 1.0221 \\
C6E & 13 & 0.00 & 2.89 & 1.1061 & 0.8400 \\
C7E & 13 & 0.00 & 2.60 & 0.8863 & 1.1335 \\
C8E & 13 & 0.00 & & 1.0287 \\
\hline
\end{tabular}

The mean contamination levels of water, the minimum, maximum and standard deviation in $\log _{10} \mathrm{CFU} / \mathrm{ml}$

Table 2: Comparison of heterotrophic plate counts of source waters, prepoint-of-use samples and effluent water ${ }^{1}$

\begin{tabular}{|c|c|c|c|c|c|c|c|c|c|c|}
\hline Tap & Prebase & C1 & $C 2$ & C3 & C4 & C5 & C6 & $C 7$ & C8 & \\
\hline Tap & N/A & $<0.05$ & - & & - & & - & & - & \\
\hline Prebase & & N/A & $<0.05$ & & $<0.05$ & & $<0.05$ & & $<0.05$ & \\
\hline C1 & & & N/A & - & $<0.05$ & $<0.05$ & $<0.05$ & $<0.05$ & - & - \\
\hline C2 & & & & $\mathrm{N} / \mathrm{A}$ & $<0.05$ & $<0.05$ & $<0.05$ & - & - & - \\
\hline C3 & & & & & N/A & - & $<0.05$ & - & - & - \\
\hline C4 & & & & & & N/A & $<0.05$ & $<0.05$ & - & - \\
\hline C5 & & & & & & & N/A & - & $<0.05$ & $<0.05$ \\
\hline C6 & & & & & & & & $\mathrm{N} / \mathrm{A}$ & $<0.05$ & $<0.05$ \\
\hline C7 & & & & & & & & & N/A & - \\
\hline $\mathrm{C} 8$ & & & & & & & & & & N/A \\
\hline
\end{tabular}

${ }^{1}$ All groups were analyzed using one-way analysis of variance and Scheffe's posthoc test at alpha $=0.05$.

The $\mathrm{pH}$ of water from the municipal water supply was about 7.7, while that of the water with iodine ranged between 6.4 and 6.8. Table 3 lists the values in $\mathrm{mg} / \mathrm{l}$ of the EPA method 502.2 for trihalomethanes and volatile organic compounds showing that using elemental iodine in the presence of organic matter did not produce trihalomethanes greater than the US EPA permissible limits.

Scanning electron micrographs of the baseline and poststudy representative line samples are in Figure 2. Waterline samples taken at baseline from clean lines $(\mathrm{C} 1-\mathrm{C} 4)$ showed no biofilm contamination. Baseline samples from waterlines from groups C5 - C8 showed established biofilm. Waterline samples taken at the end of the study from either C1 or C2 demonstrated reorganization of biofilm and forming chains of rod-like structures and the presence of microorganisms, demonstrating that clean lines when not treated with iodine became contaminated with biofilm. End of study waterline sample from C3 or C4 showed no biofilm formation, but showed the presence of discreet microorganisms scattered on the surface indicating the possibility that constantly present low levels of iodine could hinder formation of biofilm. Waterlines with no iodine in the lines showed mature biofilm formation and conversely, those with low levels of iodine demonstrated disruption of the existing mature biofilm.

\section{DISCUSSION}

As of today, the US FDA has not cleared biofilm removal/ eradication claim for any chemical or physical method (only control claims if any are given). Any antimicrobial method or device that has such a claim in the United States of America must be registered by the US-EPA as a pesticide prior to introduction into the marketplace. As previously mentioned, the microbial quality and mineral content of tap 
Effects of lodine in Microbial Control of Dental Treatment Water

\begin{tabular}{|c|c|c|c|c|c|}
\hline & URC sample \# & $81223-42$ & $81223-43$ & $81223-44$ & $81223-45$ \\
\hline Sample & & C1 (no iodine) & C4 (lodine at base) & C6 (no iodine) & C7 (lodine in bottle) \\
\hline Test & Units & Test results & Test results & Test results & Test results \\
\hline $\mathrm{CHCl}_{3}$ & $\mathrm{mg} / \mathrm{l}$ & 0.0160 & ND@0.0005 & 0.0293 & ND@0.0005 \\
\hline $\mathrm{CHCl}_{2} \mathrm{Br}$ & $\mathrm{mg} / \mathrm{l}$ & 0.0048 & ND@0.0005 & 0.0045 & ND@0.0005 \\
\hline $\mathrm{CHClBr}_{2}$ & $\mathrm{mg} / \mathrm{l}$ & 0.0012 & ND@0.0005 & 0.0034 & ND@0.0005 \\
\hline $\mathrm{CHBr}_{3}$ & $\mathrm{mg} / \mathrm{l}$ & ND@0.0005 & ND@0.0005 & ND@0.0005 & ND@0.0005 \\
\hline Total trihalomethanes & $\mathrm{mg} / \mathrm{l}$ & 0.0220 & ND@0.0020 & 0.0372 & ND@0.0020 \\
\hline
\end{tabular}

EPAs permissible limit $=0.1000 \mathrm{mg} / \mathrm{l}$. All units (with or without exposure to iodine) measured showed lesser than the US EPA permissible limits of individual or total trihalomethanes

water varies depending upon processing, distance from the processing plant, inherent mineral content, as well as seasonal variations. Purely by cleaning/disinfecting the lines periodically, one cannot ensure that tap water can meet the requirements. It is imperative there be a control over the quality of water to be used in the event of 'boil water alerts' in the community. One way to control contamination would be to retrofit the DUW system with a self-contained reservoir and detach the water system from the municipal water source. Some of the methods for controlling dental treatment water contamination are as follows:

\section{Chemical Treatment of DUW}

Chemical treatment with constantly present chemicals to control the microbes and biofilms in DUWLs is a viable option available to dentists. When selecting chemicals, it is necessary to use safe chemicals or safe methods in treating waterlines. The chemicals selected must be approved by the FDA for use in the jurisdiction of the United States, safe for patients, noncorrosive to the components of the DUW system and compatible with other restorative materials used in the patient's mouth.

\section{Chemical Methods Approved by the US-FDA}

\section{Periodic Cleaning Agents}

1. Dentacide ${ }^{\circledR}$ (iodine radical) is a periodic cleaning agent that has been developed to clean DUWLs (Biomedical Development Corporation). A self-contained water system is needed to use this chemical. Lines need to be loaded with the chemical daily (overnight contact) and emptied in the morning. Lines need to be flushed with water to remove residues of the chemical. It has been shown that biofilms are controlled by this method and is found to be safe on the waterline metals and materials. When this method is used, it is efficacious to use microbe-free water to consistently meet the ADA's goal. If tap water is used, then the level of contamination in the dental treatment water is dependent on the contamination in the tap water. Patient exposure and employee exposure are issues that need to be studied. Pasteurized, distilled (in-house) or sterile water is needed for optimal microbial control during patient care.

2. Sterilex ${ }^{\circledR}$ Ultra-Kleen (Sterilex ${ }^{\circledR}$ Corporation, Hunt Valley, MD, USA) is a chemical that is designed for use on a weekly basis. The $\mathrm{pH}$ of this device after mixing is very high ( $>11)$. The chemical is granular and has to be mixed with hot water to be completely dissolved prior to loading the lines. The contact period is overnight. Data are still lacking on equipment, personnel and patient safety. This chemical is considered to be safer on the DUWLs than bleach. As with Dentacide, it is efficacious to use microbe-free water. If tap water is used, then the level of contamination in the dental treatment water is dependent on the contamination in the tap water. Pasteurized, distilled (in-house) or sterile water is needed for optimal microbial control during patient care.

3. Chlorine Dioxide VistaTabs ${ }^{\mathrm{TM}}$ (Vista Research Group, LCC, Ashla and, OH, USA) is a self-dissolving tablet that is used for biofilm control. Although approved for cleaning biofilms, studies need to be conducted on this device with respect to biofilm control and compatibility with dental unit water systems, metals and non-metal components of the dental unit water system.

\section{Constantly Present Chemicals}

1. Citric acid $0.21 \%$ (Bioclear) is a constantly present solution that is used as an irrigant. Citric acid is considered to be 'Generally recognized as safe' (GRAS) acid and is used extensively in the food and medical industry. Sensitivity to citric acid has not been documented. This chemical is very effective in microbial control of the treatment water. Biofilm removal is very slow but secular. It has been cleared as a low-level disinfectant for the dental unit waterlines. This is the only chemical that has efficacy data on specific organisms (P. aeruginosa, S. aureus, E. coli, $K$. pneumonia, C. albicans). Independent studies have shown that it is safe on waterline metal and materials 


\begin{tabular}{|c|c|c|}
\hline & Bas & End of study \\
\hline 흠 & $\begin{array}{l}\text { - Clean lines at } \\
\text { baseline } \\
\text { - No biofilms } \\
\text { - Very few microbes }\end{array}$ & $\begin{array}{l}\text { - Lines contaminated } \\
\text { - Biofilm present, no } \\
\text { mature matrix } \\
\text { - Significant number } \\
\text { of microbes }\end{array}$ \\
\hline 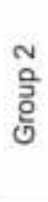 & $\begin{array}{l}\text { - Clean lines at } \\
\text { baseline } \\
\text { - No biofilms } \\
\text { - Significant number } \\
\text { of microbes }\end{array}$ & $\begin{array}{l}\text { - Lines contaminated } \\
\text { - Biofilm present, no } \\
\text { mature matrix } \\
\text { - Significant number } \\
\text { of microbes }\end{array}$ \\
\hline m & $\begin{array}{l}\text { - Clean lines at } \\
\text { baseline } \\
\text { - No biofilms } \\
\text { - Significant number } \\
\text { of microbes }\end{array}$ & $\begin{array}{l}\text { - Lines contaminated } \\
\text { - Biofilm not present } \\
\text { - Significant number } \\
\text { of microbes }\end{array}$ \\
\hline 造 & $\begin{array}{l}\text { - Clean lines at } \\
\text { baseline } \\
\text { - No biofilms } \\
\text { - Very few microbes }\end{array}$ & $\begin{array}{l}\text { - Lines contaminated } \\
\text { - Biofilm not present } \\
\text { - Significant number } \\
\text { of microbes }\end{array}$ \\
\hline 을 & $\begin{array}{l}\text { - Lines contaminated } \\
\text { - Biofilm present, no } \\
\text { mature matrix } \\
\text { - Significant number } \\
\text { of microbes }\end{array}$ & $\begin{array}{l}\text { - Lines contaminated } \\
\text { - Mature biofilm } \\
\text { matrix present all } \\
\text { over the field }\end{array}$ \\
\hline $\begin{array}{l}0 \\
\frac{2}{2} \\
\text { 인 }\end{array}$ & $\begin{array}{l}\text { - Lines contaminated } \\
\text { - Mature biofilm } \\
\text { matrix present all } \\
\text { over the field }\end{array}$ & $\begin{array}{l}\text { - Lines contaminated } \\
\text { Mature biofilm } \\
\text { matrix present all } \\
\text { over the field }\end{array}$ \\
\hline 을 & $\begin{array}{l}\text { - Lines contaminated } \\
\text { - Mature biofilm } \\
\text { matrix present all } \\
\text { over the field }\end{array}$ & $\begin{array}{l}\text { - Lines contaminated } \\
\text { - Biofilm present, no } \\
\text { mature matrix } \\
\text { - Significant number } \\
\text { of microbes }\end{array}$ \\
\hline $\begin{array}{l}\infty \\
\text { 을 } \\
\text { ㅇํㄴ }\end{array}$ & $\begin{array}{l}\text { - Lines contaminated } \\
\text { Mature biofilm } \\
\text { matrix present all } \\
\text { over the field }\end{array}$ & $\begin{array}{l}\text { - Lines contaminated } \\
\text { mature biofilm present all } \\
\text { over the field } \\
\text { - Some sloughing } \\
\text { noted }\end{array}$ \\
\hline
\end{tabular}

Fig. 2: Scanning electron microscopy of waterlines at baseline and end of study $(400 \times)$

when used per manufacturer's recommendations. Lines need to be emptied daily and over weekends for optimal safety. It is safe on patients and employees.

2. Chlorhexidine $0.12 \%$ (a) Lines by Micrylium Inc.; and (b) Mint-a-Kleen by Anodia Systems are specifically formulated for use as irrigants and now as periodic cleaners. They are safe on patients and employees without allergies or hypersensitive reaction to CHG.

In this short-term study, we tested the prototypes of the iodine eluting cartridges and found that low levels of iodine controlled microbes in the effluent water, but did not show biofilm removal over a period of 3 months. When using low levels of iodine in waterlines, it is necessary to use the dental unit on a regular basis so that the inherent volume of the lines is replaced often with a fresh dose of the 2 to $6 \mathrm{ppm}$ of iodine. If the lines are not used regularly, the available iodine may be depleted, thereby allowing recolonization of the lines. An advantage of using these iodine cartridges is that it reduces the personnel time as it acts as an engineering control (reducing personnel 
manipulation of the water system and variations in protocols of waterline management). It has shown promise in the contamination control of municipal water and has rendered it viable for dental treatment. Biofilm control/ disruption without eradication was observed in this 6-week study. A more detailed evaluation using a longer period is warranted for a more definitive inference on biofilm disruption.

\section{CONCLUSION}

In this study found that low levels of elemental iodine in dental treatment water was found to be effective in meeting the 2003 CDC guidelines of $<200 \mathrm{CFU} / \mathrm{ml}$ for dental treatment water. We also found that the dental unit water system should be initially periodically cleaned with a biofilm control agent for effective biofilm control.

\section{REFERENCES}

1. Peters E, McGaw W. Dental unit water contamination. J Can Dent Assoc 1996;62(6):492-95.

2. Shearer B. Biofilm and the dental office. JADA 1996; 127(2): 181-89.

3. Costerton WJ, Cheng KJ, Genes GG, et al. Bacterial biofilms in nature and disease. Ann Rev Microbiol 1987;41:435-64.

4. Scarbeck K. Dental unit waterlines-curbing infectious midstream. AGD Impact 1993;21(10):6-12.

5. Lizotte JR, Peters E, Whitehouse R. Influence of biofilms on microbial contamination in dental unit water. J of Dent 1991; 19(5):290-95.

6. Sawyer DR, Page DG, Sweeney W, Dalton HP. Bacterial contamination and disinfection of the dental handpiece and the water it delivers. Virginia Dent J 1976;53:14-23.

7. Fitzgibbon EJ, Bartzokas CA, Martin MV, Gibson MF, Graham $\mathrm{R}$. The source, frequency and extent of bacterial contamination of dental unit water systems. Brit Dent J 1984;157(98):98-101.

8. Neff Jh, Rosenthal SL. A possible means of inadvertent transmission of infection to dental patients. J Dent Res 1957; 36:932-34.

9. Blake GC. The incidence and control of bacterial infection in dental spray reservoirs. Brit Dent J 1963;115:413-16.

10. Moriarty JD, Crawford JJ. Evaluation of an independent sterile water reservoir system for high-speed instrumentation. J Dent Res 1976; abstract \#855:B275.

11. Oppenheim BA, Sefton AM, Gill ON, et al. Widespread Legionella pneumonphila contamination of dental stations in a dental school without apparent human infection. Epidemiol and Infect 1987;99:159-66.

12. Pankhurst CL, Philpott-Howard JN, Hewitt JH, Casewell MW. The efficacy of chlorination and filtration in control and eradication of Legionella from dental chair water systems. J of Hosp Infect 1990;16:9-18.

13. Center for disease control. Guidelines for Infection Control in Dental Health-Care Settings 2003: Guidlines and Reports 2003; 52(RR17).

14. Fayle SA, Pollard MA. Decontamination of dental unit water systems: A review of current recommendations. Brit Dent J 1996; 181:369-72.

15. Samaranayke LP, Scheutz F, Cottone J. Infection control for the dental team. Copenhagen Munksgaard 1991;98-99.
16. Samaranayke LP. Handpiece and waterline decontamination and HIV transmission: A critique. Dent Update 1993;20:53-56.

17. US Department of Health and Human Services Recommended Infection Control Practices for Dentistry. MMWR 1993;42: no. RR-8.

18. Williams JF, Johnston AM, Johnson B, Huntington MK, Mackenzie CD. Microbial contamination of dental unit waterlines: Prevalence, intensity and microbiological characteristics. JADA 1993;124:59-65.

19. Kellet M, Hobrook WP. Bacterial contamination of dental handpieces. J Dent 1980;8:249-53.

20. Blake GC. The incidence and control of bacterial infection in dental spray reservoirs. Brit Dent J 1963;115:413-20.

21. Abel IC, Miler RL, et al. Studies on dental aerobiology: (IV). Bacterial contamination of water delivered by dental units. J Dent Res 1971;50:1567-69.

22. Meiller T, Baqui A, DePaola L, Overholser CD. Disinfection of dental unit waterlines using Listerine antiseptic. J Dent Res 1995;74:153.

23. Puttaiah R, Slattery P, Plamondon TJ, Mills SE, Cottone JA. Effects of two different source waters and cleaning dental unit water systems. J Dent Res 1997;76 (special issue), abstract \#2165:284.

24. Puttaiah R, Mills SE, Plamondon TJ, Thrash WJ, Cottone JA. A multi-group longitudinal study of dental unit waterline contamination. J Dent Res 1996;75 (special issue), abstract \#3176: 414.

25. Puttaiah R, Waggoner MB, Sherman LE, Bryan WR, Kim PJ. Efficacy of citric acid in controlling biofilms in dental unit waterlines. J Dent Res 1998; 77 (special issue), abstract \#1759: 851.

26. Puttaiah R, Cederberg R, Wneck R. Efficacy of chlorhexidine in controlling biofilm contamination of dental unit waterlines. J Dent Res 1998;77 (special issue A), abstract \#1255: 262.

27. Dietary Reference Intakes, National Academy of Sciences. Washington, DC: National Academy Press, 2001.

28. Pennington, Jean AT. A review of iodine toxicity reports. J Am Diet Assoc 1990;90:1571-81.

29. Standard Methods for the Examination of Water and Wastewater, American Water Works Association, Leuco Violet Methods for Iodine and Iodide.

30. EPA Method 502.2, Volatile Organic Compounds in Water by Purge and Trap Capillary Column Gas Chromatography with Photoionization and Electrolytic Conductivity Detectors in Series, Revision 2.1, 1995.

\section{ABOUT THE AUTHORS}

\section{Raghunath Puttaiah}

(Corresponding Author)

Associate Professor, Diagnostic Sciences, Texas A\&M University System Health Science Center, Baylor College of Dentistry, 3302 Gaston Ave, Dallas, Texas 75246, USA, Phone: (214) 828-8245, Fax: (214) 828-8306, e-mail: rputtaiah@bcd.tamhsc.edu

\section{Jeff Seibert}

Private Clinical Practice, West Main Street, Lewisville, Texas, USA

\section{Robert Spears}

Associate Professor, Biomedical Sciences, Texas A\&M University System Health Science Center, Baylor College of Dentistry, Dallas Texas, USA 